nuôi cấy tế bào được thêm vào mỗi mẫu.

- Sau khi tế bào - giàn scaffold được nuôi cấy 2-14 ngày, môi trường nuôi cấy được bổ sung MTT (3 - (4,5 - dimethylthiazol -2 -yl) -2,5diphenyltetrazolium bromide) $1,2 \mathrm{mM}$ và sau đó được ủ ở $37^{\circ} \mathrm{C}$ trong $4 \mathrm{~h}$. Sự chuyển màu xanh đen của MTT từ ty thể của tế bào sống để kiểm tra sư phân bố của tế bào trong giàn scaffold.

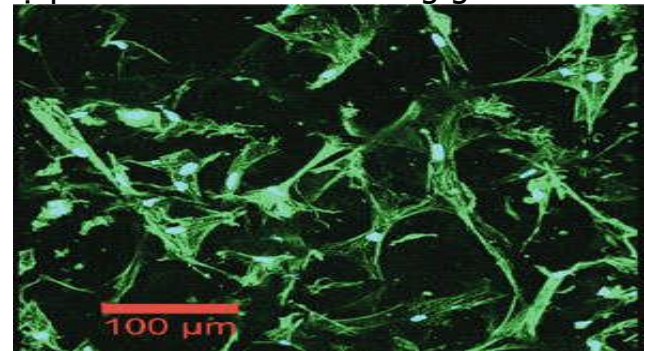

Hinh 2.4. Hình ảnh hiển vi điện tử cấu trúc cắt ngang của giàn scaffold collagen khoáng 3D, các hMSC đã bám vào và được nuôi cấy dưới sự kích thích của mô sinh xương. Bên trái: hình ảnh tiêu bản LSM, sau 18 ngày nuôi cãy. Màu xanh lá cây là bộ xương actin, màu xanh da trời huỳnh quang là nhân tế bào. (Dr. M. Kruse). Bên phải: hình ảnh hiển vi điện tử quét SEM sau 28 ngày nuôi cấy (M. Glensky và cộng sự).

\section{KẾT LUÂ̂N}

Cùng với sự phát triển công nghệ tế bào gốc là sự phát triển công ghệ scaffold bởi lẽ tế bào gốc cần một giá đỡ để bám dính, tăng sinh và biệt hoá thành các tế bào của mô, tổ chức bị tổn thương. Giá đõ̃ vừa có vai trò "làm tổ" cho tế bào gốc, vừa định hướng, "homming" cho tế bào gốc hoạt động tại vị trí cần tế bào gốc. Bằng các công nghệ hiện đại cùng với sự đầu tư của các nhà khoa học, những ứng dụng cây ghép tế bào gốc trong y học tái tạo sẽ ngày càng phát triển và hứa hẹn sẽ giải quyết được những thách thức chung trong điều trị bệnh hiện nay.

\section{TÀI LIỆU THAM KHẢO}

1 Beresford JN, Joyner CJ, Devlin C, Triffitt JT. The effects of dexamethasone and 1,25dihydroxyvitamin D3 on osteogenic differentiation of human marrow stromal cells in vitro. Arch Oral Biol. 1994; 39:941-947.

2 Jagodzinski M, Breitbart A, Wehmeier M, Hesse E, Haasper C, Krettek C, Zeichen J, Hankemeier S. Influence of perfusion and cyclic compression on proliferation and differentiation of bone marrow stromal cells in 3-dimensional culture. J Biomech. 2008; 41:1885-1891.

3 Tsiridis E, Bhalla A, Ali Z, Gurav N, Heliotis M, Deb S, DiSilvio L. Enhancing the osteoinductive properties of hydroxyapatite by the addition of human mesenchymal stem cells, and recombinant human osteogenic protein-1 (BMP-7) in vitro. Injury 2006; 37(Suppl3):S25-S32.

4 Michael Gelinsky, Anja Lode, Anne Bernhardt, and Angela Rösen- Wolff. Stem Cell Engineering for Regeneration of Bone Tissue. Stem Cell Engineering. 2011; 383-399. Lode A, Bernhardt A, Boxberger $S$, Gelinsky $M$. Cultivation of mesenchymal stem cells on a three-dimensional artificial extracellular bone matrix. Proceedings of the International Conference "Biomaterials in Regenerative Medicine", Nadolny AJ, ed. Conference Proceedings and

\title{
ĐÁNH GIÁ KẾT QUẢ SỬ DỰG NICARDIPINE TIÊM VÀO ĐộNG MẠCH VÀNH Ở BÊ̂NH NHÂN Có DÒNG CHẢY CHẬM ĐộNG MẠCH VÀNH
}

\author{
Nguyễn Đình Công*, Trương Thanh Hương**, Bùi Long***
}

\section{TÓM TẮT}

Tổng quan: Dòng chảy chậm động mạch vành là một nguyên nhân gây đau ngực không phải hiếm gặp, hiện tượng này đặc trưng bởi sự chậm đổ đầy cản quang trên hình chụp mạch vành qua da ở những bệnh nhân không có hẹp đáng kể lòng mạch. Nicardipine là một loại thuốc theo kinh nghiệm có thể

*Bênh viên Thanh Nhàn

**Viện Tim mạch Việt Nam - Bênh viện Bạch Mai

***Bêenh viện Hữu Nghi Việt-Xố

Chịu trách nhiệm chính: Nguyễn Đình Công

Email: nguyendinhcong91.md@gmail.com

Ngày nhận bài: 10.9.2021

Ngày phản biên khoa hoc: 29.10.2021

Ngày duyệt bài: 11.11.2021 cải thiên dòng chảy nhưng chưa được đưa vào phác đồ thường quy. Mục tiêu: Đánh giá tính an toàn và hiêu quả cải thiên dòng chảy của nicardipine khi tiêm trực tiếp vào động mạch vành ở bệnh nhân có dòng chảy châm. Phướng pháp nghiên cứu: Nghiên cứu mô tả cắt ngang trên 34 bệnh nhân. Tiêu chuẩn lựa chọn là bệnh nhân có hình chụp mạch vành với dòng chảy TIMI $<3$ và/hoặc CTFC $\geq 14$, kèm theo không có hep $\geq 40 \%$ đường kính đông mach vành thương tâm mạc. Nicardipine được sử dụng với liều 100-200 $\mu \mathrm{g}$, ngay sau đó mach vành được chup lai. Tính an toàn được đánh giá bởi thay đổi mạch, huyết áp, triệu chứng trước và sau chụp. Hiêu quả cải thiện dòng chảy được đánh giá bởi thay đổi TIMI và CTFC, tốc độ hình chụp quy ước là 15 hình/giây. Kết quả: Nghiên cứu bao gồm 20 nam và 14 nữ, tuối trung bình $65 \pm$ 9, BMI trung bình là 23,2 $\pm 2,4$, triệu chứng nhập viện 
chính là đau ngực (79\%). Huyết áp tâm thu trước và sau dùng thuốc giảm từ $127 \pm 18$ xuống $116 \pm 14$ $\mathrm{mmHg}$, huyết áp trung bình giảm từ $100 \pm 13$ xuống $92 \pm 12 \mathrm{mmHg}$, không có trường hợp nào huyết áp tâm thu giảm xuống thấp hơn $90 \mathrm{mmHg}(p<0,001)$, tần số tim thay đổi từ $73 \pm 12$ thành $75 \pm 12(\mathrm{p}<$ $0,001)$. Trước dùng thuốc, dòng chảy châm đước quan sát ở 66/102 mạch máu (65\%), TIMI trung bình 2,4 \pm 0,5 , tất cả mach máu đat TIMI 3 sau tiêm thuốc. CTFC cải thiện từ $26,3 \pm 6,8$ xuống $10,6 \pm 3,7$ ( $p<0,001)$. Chỉ có 2 bệnh nhân $(5,9 \%)$ có triệu chứng đau ngực thoáng qua sau dùng thuốc. Liều $100 \mu \mathrm{g}$ và $200 \mu \mathrm{g}$ đạt hiệu quả giảm CTFC tương đương, theo thứ tự là $10,9 \pm 4$ và $10,4 \pm 3(p=0,601)$. Kết luận: Nicardipine cho thây hiệu quả cải thiện dòng chảy tốt ở bệnh nhân dòng chảy chậm mà không gây ảnh hưởng nhiều đến huyết động. Liều $100 \mu \mathrm{g}$ cho thấy hiệu quả không kém hơn liều $200 \mu \mathrm{g}$ trong nghiên cứu.

Tư khóa: dòng chảy chậm động mạch vành, nicardipine

\section{SUMMARY}

\section{SAFETY AND EFFICACY OF INTRACORONARY NICARDIPINE IN THE TREATMENT OF CORONARY SLOW FLOWPHENOMANON}

Background: Coronary slow flow phenomenon (CSFP) is not a rare cause of chest pain, characterized by delayed coronary opacification during diagnostic angiography in the absence of epicardial coronary artery disease. Nicardipine is a drug used by experience that has capacity to improve coronary flow but not available in current algorithm of treatment. Objective: Assess the safety and efficacy of intracoronary nicardipine in the treatment of CSFP. Methods: the effect of intracoronary nicardipine was evaluated in 34 patients. CSFP was defined as delayed coronary flow with TIMI flow grade $<3$ and/or corrected TIMI frame count (CTFC) $\geq 14$ during diagnostic coronary angiography in the absence of obvious epicardial coronary stenosis ( $\geq 40 \%)$. Nicardipine was administered as 100 or $200 \mu \mathrm{g}$ bolus, after which repeat angiography was performed. Safety was assessed by systolic and average blood pressure and pulse. Coronary flow before and after nicardipine was evaluated by TIMI and CTFC with set-up speed 15 frames per second. Results: Our study population consists of 20 males and 14 females, mean age $65 \pm 9$, mean BMI 23,2 $\pm 2,4$, the most popular clinical presentation was rest angina (79\%). The before and after systolic blood pressre declined from $127 \pm 18$ down to $116 \pm 14$, the average blood press respectively was $100 \pm 13$ and $92 \pm 12$, no patient has systolic blood pressure lower than $90 \mathrm{mmHg}$ after nicardipine bolus $(p<0,001)$, heart rate slighly increased from $73 \pm 12$ to $75 \pm 12(p<0,001)$. The slow flow phenamanon was observed in 66/102 epicardial vessels $65 \%$ ), the mean

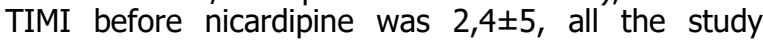
vessel gained TIMI 3 flow after administering. CTFC improved from $26,3 \pm 6,8$ before nicardipine to $10,6 \pm 3,7$ after the drug administration. The 100 and $200 \mu \mathrm{g}$ dose have no statistically significant different effect with CTFC 10,9 \pm 4 and $10,4 \pm 3$ after nicardipine $(p=0,601)$. Only 2 patients $(5,9 \%)$ have transient chest pain after bolus of the drug. Conclusions: Intracoronary Nicardipine showed highly effectiveness in reversing slow flow phenamanoncho without affecting much of the blood pressure and heart rate. The dose $100 \mu \mathrm{g}$ was not lesser than $200 \mu \mathrm{g}$ in improving slow flow.

Keywords: coronary slow flow phenomenon, nicardipine

\section{I. ĐẶT VẤN ĐỀ}

Hiện tượng dòng chảy chậm động mạch vành là một hiện tượng về mặt hình ảnh học trong chụp động mạch vành qua da, đặc trưng bởi sự chậm đổ đầy thuốc cản quang tới đoạn xa của động mạch vành thượng tâm mạc dù trên hình ảnh không quan sát được tổn thương hẹp lòng mạch có ý nghĩa nào. Mặc dù đây là một hiện tượng đã được biết đến qua nhiều thập kỉ, bệnh sinh và cơ chế của dòng chảy chậm động mạch vành vẫn chưa được hiểu một cách đầy đủ. Không chỉ là một hiện tượng trên hỉnh ảnh thuần túy, dòng chảy chậm động mạch vành có mối tương quan trực tiếp đến các biểu hiện lâm sàng của bệnh lý thiếu máu cơ tim, các rối loạn nhịp đe dọa tính mạng, đột tử và hội chứng vành cấp tái phát ${ }^{1,2}$. Hiện tượng dòng chảy chậm được báo cáo lên đến xấp xỉ 7\% ở những bệnh nhân được chụp động mạch vành chẩn đoán và khoảng $4 \%$ bệnh nhân nhập viện vì triệu chứng đau ngực không ổn định ${ }^{3,4}$.

Nhiều loại thuốc đã được sử dụng cho thấy hiệu quả trong cải thiện dòng chảy chậm động mạch vành trong quá trình chụp và can thiệp động mạch vành qua da, trong đó Nicardipine, một thuốc chẹn kênh calci nhóm dihydropyridine, đã được cho thấy có hiệu quả cải thiện dòng chảy mạch vành tốt và ít làm giảm co bóp cơ tim, tuy nhiên chưa được sử dụng thường quy trong thực hành lâm sàng ${ }^{5}$.

\section{II. ĐỐI TƯỢNG VÀ PHƯƠNG PHÁP NGHIÊN CỨU}

Hiêu quả của nicardipine được đánh giá trên 34 bệnh nhân được chụp động mạch vành tại bốn trung tâm ở thành phố Hà Nội từ 6-2020 đến 10-2021. Tiêu chuẩn lựa chọn khi có ít nhất một đông mach vành thượng tâm mac quan sát được hình ảnh dòng chảy chậm với TIMI < 3 và/hoặc CTFC $\geq 14$, kèm theo không có hẹp lòng mạch $\geq 40 \%$ và được sử dụng nicardipine tiêm trực tiếp vào động mạch vành với mục đích cải thiện dòng chảy. Tiêu chuẩn loại trừ là bệnh nhẩn có bênh cảnh nhồi máu cơ tim cấp hoặc bệnh lý cấp tính nặng khác, bênh nhân có rỗi loạn huyết động, dãn động mạch vành, sử dụng các chất kích thích hoặc bệnh nhân không đồng ý tham gia nghiên cứu. 


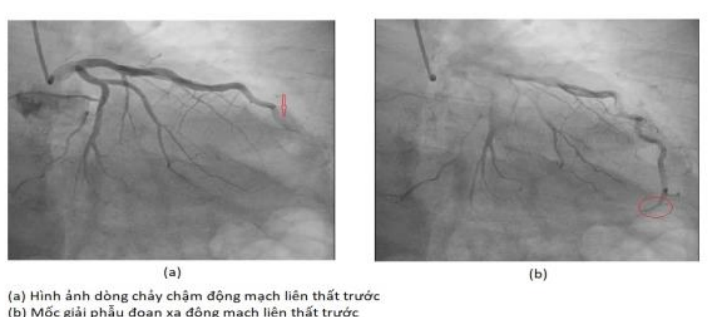

Phương pháp nghiên cứu là mô tả cắt ngang. Nicardipine được pha loãng trong dung dịch Natri clorid $0,9 \%$ để đạt nồng độ $100 \mu \mathrm{g} / \mathrm{ml}$, trên động mach vành có dòng chảy chậm, nicardipine được tiêm với liều $100 \mu \mathrm{g}$ hoặc $200 \mu \mathrm{g}$, sau đó mạch vành được chụp lại với cùng góc chụp. Tiêu chí đánh giá độ an toàn là huyết áp tâm thu, huyết áp trung bình và tần số tim. Tiêu chí đánh giá dòng chảy là phân độ TIMI và khung hình TIMI hiệu chỉnh (CTFC) dựa trên tiêu chuẩn của Gibson và cộng sự . TIMI $<3$ và/hoặc CTFC $\geq$ 14 được xem là dòng chảy chậm.

Xử lý số liệu và phân tích bằng phần mềm thống kê y học SPSS 26.0. Sử dụng các thuật toán: tần suất, tỷ lệ với các biến định tính; trung bình, phương sai với các biến định lượng; các test thống kê để kiểm định, mức khác biệt có ý nghĩa $p<0,05$.

\section{KẾT QUẢ NGHIÊN CỨU}

Các đặc điểm lâm sàng và cận lâm sàng của đối tượng nghiên cứu được tóm lược ở bảng 1 . Nhóm bệnh nhân nghiên cứu bao gồm 20 nam và 14 nữ, tuổi trung bình là $65 \pm 9$ (thấp nhất 46 , cao nhất 83 tuổi). BMI trung bình là 23,2 22,4. Triệu chứng nhập viện phổ biến nhất là đau ngực (79\%). Yếu tố nguy cơ nhiều nhất là tăng huyết áp (76,5\%), rối loạn chuyển hóa lipid máu $(67,6 \%)$, thuốc sử dụng nhiêu nhất là ức chế men chuyển/chẹn thụ thể $(58,8 \%)$ và statins $(35,3 \%)$.

Trên hình ảnh chụp mạch vành, có $66 / 102$ (64,7\%) mạch máu có hiện tượng dòng chảy chậm được sử dụng nicardipine, trong đó $L A D$ là $31(46,97 \%)$, LCX là $24(36,36 \%)$, RCA là 11 $(16,67 \%)$.

\begin{tabular}{|c|c|}
\hline & $\mathbf{N}=\mathbf{3 4}$ \\
\hline Tuổi (năm) & $65 \pm 9$ \\
\hline Giới nam $(\mathrm{n}, \%)$ & $20(58,8 \%)$ \\
\hline BMI $(\mathrm{kg} / \mathrm{m} 2)$ & $23,2 \pm 2,4$ \\
\hline Tăng huyết áp & $76,5 \%$ \\
\hline Đái tháo đường & $29,4 \%$ \\
\hline Rối loạn chuyến hóa lipid máu & $67,6 \%$ \\
\hline Hút thuốc lá & $11,8 \%$ \\
\hline
\end{tabular}

\begin{tabular}{|c|c|}
\hline \multicolumn{2}{|c|}{ Thuốc } \\
\hline $\begin{array}{c}|c| \\
\text { Uc chế men chuyê̂́n/ } \\
\text { chẹn thụ thể }\end{array}$ & $58,8 \%$ \\
\hline Chẹn kênh calci & $14,7 \%$ \\
\hline Chẹn beta giao cảm & $17,6 \%$ \\
\hline Statins & $35,3 \%$ \\
\hline LVEF (\%) & $67,94 \pm 7,66$ \\
\hline Dd (mm) & $43,94 \pm 5,29$ \\
\hline Creatinin máu (mmol/l) & $89,64 \pm 37,01$ \\
\hline
\end{tabular}

Huyết áp tâm thu trước và sau dùng thuốc lần lượt là $127 \pm 18$ và $116 \pm 14$, mức giảm là $11 \pm 6 \mathrm{mmHg}(p<0,001)$, không có trường hợp nào huyết áp tâm thu giảm xuống dưới 90 $\mathrm{mmHg}$. Huyết áp trung bình trước và sau dùng thuốc là $100 \pm 13$ và $92 \pm 12(p<0,001)$. Tần số tim trước và sau dùng thuốc là $73 \pm 12$ và $75 \pm$ $12(p<0,001)$. Có 2 bênh nhân có triệu chứng đau ngực thoáng qua sau tiêm thuốc.

Về đánh giá hiệu quả dòng chảy, phân độ TIMI trung bình trước dùng thuốc là $2,4 \pm 0,5$, tất cả mạch nghiên cứu đều đạt dòng chảy TIMI 3 sau dùng thuốc. CTFC cải thiện từ 26,3 $\pm 6,8$ xuống còn 10,6 $\pm 3,7$ sau khi sử dụng nicardipine $(p<0,001)$. Sự cải thiện CTFC được quan sát thấy ở cả ba động mạch vành thượng tâm mạc. Có 32

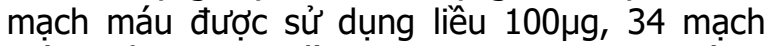
máu sử dụng liều $200 \mu \mathrm{g}$, sau khi dùng nicardipine, CTFC của hai nhóm liều không có sự khác biệt, lần lượt là $10,9 \pm 4,2$ và $10,4 \pm 3,1$ $(p=0,601)$.

\section{BÀN LUÂNN}

Nhiều nghiên cứu cho thấy hiên tượng dòng chảy chậm hay gặp ở nam giới tuổi trung niên và có tỉ lệ hút thuốc lá cao, nhóm bệnh nhân này thường nhập viện với triệu chứng đau ngực khi nghỉ kèm theo biến đổi dạng thiếu máu cớ tim không điển hình ở điện tâm đồ bề mặt và có test gắng sức âm tính. Điều này khác với hội chứng $X$ cổ điển khi hay gặp ở nữ sau mãn kinh với triệu chứng đau ngực khi gắng sức và test gắng sức có biểu hiện thiếu máu cơ tim7. Tỉ lệ nam giới chiếm ưu thế trong hầu hết các nghiên cứu về hiện tượng dòng chảy chậm, trong nghiên cứu của chúng tôi, tỉ lệ nam giới cao hơn tuy nhiên chưa có ý nghĩa thống kê do số lượng bệnh nhân còn tương đối ít ${ }^{8,}{ }^{9}$. Chỉ số khối cơ thể BMI trong nghiên cứu của chúng tôi cao hơn so với kết quả là $23,2 \pm 2,4$. Saibal và cộng sự cho rằng $\mathrm{BMI}$ là một yếu tố tiên đoán độc lập của dòng chảy chậm ${ }^{9}$. Mặt khác, béo phì cũng đã được chứng minh có mối tướng quan với suy chức năng nội mô hệ thống và tuần hoàn vành ${ }^{9}$.

Ảnh hưởng của các tổng liều nicardipine từ 


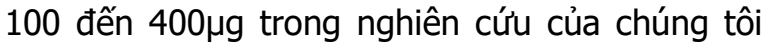
làm giảm huyết áp nhưng không gây ảnh hưởng nhiều đến huyết động lâm sàng của bệnh nhân, khi không có bệnh nhân nào có huyết áp tâm thu giảm xuống dưới $90 \mathrm{mmHg}$ và chỉ có 2 bệnh nhân có triệu chứng đau ngực thoáng qua. Trong khi so sánh liều 100 và $200 \mu \mathrm{g}$ trên từng mạch máu thì liều $100 \mu \mathrm{g}$ cho thấy hiệu quả giảm CTFC không kém hơn so với liều lượng gấp đôi. Tác giả Lambert và cộng sự đã dùng đến liều $2 m g$ tiêm vào động mạch vành nhưng không gây biến cố nào nghiêm trọng. Như vậy theo chúng tôi liều lượng khởi đầu $100 \mu \mathrm{g}$ là hợp lý với tác dụng không kém hơn các liều cao hơn.

Hình ảnh dòng chảy chậm động mạch vành có nhiều đặc điểm giống với dòng chảy chậm và không có dòng chảy trong can thiệp động mạch vành qua da, mặc dù cơ chế ít nhiều có sự khác biệt. Trong đó giả thuyết về cơ chế suy chức năng vi tuần hoàn vành và co thắt vi mạch được nhiều tác giả đồng thuận ${ }^{8}$. Nicardipine là một thuốc chẹn kênh calci thuộc dòng dihydropyridine, với tính chọn lọc cao trên kênh L-type vốn có mặt trên cơ trơn nhiều hơn cơ tim, qua việc ức chế kênh L-type này nicardipine gây giãn cớ trơn thành mạch và với ái lực cao nhưng lại ít ảnh hưởng đến chức năng co bóp cơ tim. Điều này giải thích cho tác dụng cải thiện dòng chảy của nicardipine dựa trên việc dãn vi tuần hoàn vành, đảo ngược cơ chế gây ra dòng chảy chậm ở bệnh nhân chụp cũng như can thiệp động mạch vành qua da.

Sự gia tăng trở kháng của vi tuần hoàn cũng là một yếu tố quan trọng trong cơ chế của hiện tượng dòng chảy chậm động mạch vành. Tác giả Fineschi và công sự đã chứng minh rằng trở kháng vi tuần hoàn vành tăng lên và dự trữ vành bảo tồn ở bệnh nhân có dòng chảy chậm ở điều kiện bình thường. Những bất thường vi tuần hoàn này được cho thấy có thể đảo ngược bằng các thuốc có tác dụng giãn mạch như papaverine, verapamil, diltiazem. Tuy nhiên sử dụng nicardipine tiêm trực tiếp vào động mạch vành cho thấy hiệu quả không kém hơn mà hiệu quả kéo dài hơn so với các thuốc chẹn kênh calci khác là verapamil và diltiazem. Hiệu quả này của nicardipine cũng được chứng minh là không kém hơn so với hai loại thuốc trên khi sử dụng với dòng chảy chậm và không có dòng chảy sau can thiệp động mạch vành qua da.

Hạn chế của nghiên cứu: hạn chế chủ yếu trong nghiên cứu của chúng tôi là thiết kế nghiên cứu quan sát với số lượng bệnh nhân không lơn.
Kèm theo việc lấy số liệu ở nhiều trung tâm khác nhau làm cho một số kết quả cận lâm sàng không được chuẩn hóa. Mặt khác nghiên cứu chỉ đánh giá hiệu quả tại thời điểm tiêm, không tìm hiểu được thời gian tác dụng và hiệu quả lâu dài của thuốc.

\section{KẾT LUẬN}

Nicardipine tiêm trực tiếp vào động mạch vành cho thây hiệu quả cao trong cải thiện tốc độ dòng chảy trong hiện tượng dòng chảy chậm động mạch vành mà không gây ra ảnh hưởng nhiều đển huyết động. Liều lượng $100 \mu \mathrm{g}$ nên là liều khởi đầu để đạt hiệu quả cải thiện dòng chảy và giảm thiểu tác dụng phụ của thuốc.

\section{TÀI LIẸU THAM KHẢO}

1. Horjeti B, Goda A. Acute ischemia manifestation in a patient with coronary slow flow phenomenon. Journal of electrocardiology 2012;45(3):277-9. doi: 10.1016/j.jelectrocard.2011.07.003 [published Online First: 2011/08/16]

2. Wozakowska-Kapłon B, Niedziela J, Krzyzak $\mathbf{P}$, et al. Clinical manifestations of slow coronary flow from acute coronary syndrome to serious arrhythmias. Cardiol J 2009;16(5):462-8. [published Online First: 2009/09/16]

3. Tambe AA, Demany MA, Zimmerman HA, et al. Angina pectoris and slow flow velocity of dye in coronary arteries--a new angiographic finding. Am Heart J 1972;84(1):66-71. doi: 10.1016/00028703(72)90307-9 [published Online First: 1972/07/01]

4. Mangieri E, Macchiarelli G, Ciavolella M, et al. Slow coronary flow: clinical and histopathological features in patients with otherwise normal epicardial coronary arteries. Cathet Cardiovasc Diagn 1996;37(4):375-81. doi: 10.1002/(sici)10970304(199604)37:4<375: :aid-ccd7>3.0.c0;2-8 [published Online First: 1996/04/01]

5. Pepine CJ, Lambert CR. Cardiovascular effects of nicardipine. Angiology 1990;41(11 Pt 2):978-86. [published Online First: 1990/11/01]

6. Gibson CM, Cannon CP, Daley WL, et al. TIMI frame count: a quantitative method of assessing coronary artery flow. Circulation 1996;93(5):87988. doi: 10.1161/01.cir.93.5.879 [published Online First: 1996/03/01]

7. Beltrame JF, Limaye SB, Horowitz JD. The coronary slow flow phenomenon--a new coronary microvascular disorder. Cardiology 2002;97(4):197-202. doi: 10.1159/000063121 [published Online First: 2002/07/30]

8. Mehta HH, Morris M, Fischman DL, et al. The Spontaneous Coronary Slow-Flow Phenomenon: Reversal by Intracoronary Nicardipine. J Invasive Cardiol 2019;31(3):42-45. [published Online First: 2018/12/18]

9. Huang $Q$, Zhang $F$, Chen $S$, et al. Clinical characteristics in patients with coronary slow flow phenomenon: A retrospective study. Medicine 2021;100(6) 